\title{
Analisis Filogenetik dan DNA Barcode Ektoparasit Octolasmis cor yang terifestasi pada Kepiting Bakau Scylla spp.
}

\author{
Sutianto Pratama Suherman ${ }^{* 1}$; Sulastri Arsad ${ }^{2}$ \\ 1. *Jurusan Budidaya Perairan. Fakutas Perikanan dan IImu Kelautan Universitas \\ Negeri Gorontalo, Jl. Jenderal Sudirman No. 06, Kota Gorontalo 96128, Gorontalo, \\ Indonesia \\ 2. Program Studi Manajemen SumberDaya Perairan, Fakultas Perikanan dan IImu \\ Kelautan Universitas Brawijaya, Jl. Veteran Malang 65145, Jawa Timur, Indonesia \\ *Korespodensi : sutiantopratama@ung.ac.id
}

(Diterima 02-07-2020; Direvisi 05-07-2020 Dipublikasi 25-07-2020)

\begin{abstract}
ABSTRAK
Indentifikasi morfologi memiliki keterbatasan dan hanya bisa diaplikasikan pada saat memasuki fase remaja atau dewasa, Identifikasi menggunakan sekuens DNA merupakan alternative yang dipakai dalam mengungkapkan taksonomi. Tujuan dari penelitian ini adalah mengetahui komposisi DNA dari gen 18s rRNA ektoparasit Octolasmis cor dan menganalisis filogenetik serta identifikasi spesies. Hasil menunjukan karakteristik molekuler 18 rRNA dari sampel parasit O.cor yang ditemukan di wilayah Sulawesi Selatan diperoleh panjang DNA 1500 bp dengan komposisi basa Adenin 354 (23,6\%), Guanin 444 (29,6\%), , Timin $360(24 \%)$ dan Citosin $342(15,1 \%)$. Berdasarkan hasil analisis filogentik menunjukan jarak 0,004 yang artinya memiliki kedekatan hubungan atau kemungkinan dari spesies yang sama

Kata Kunci : Analisis Filogenetik; Octolasmis cor ; 18s rRNA

\section{Phylogenetic Analysis and DNA of Ectoparasite Octolasmis cor manifested on Mud Crab Scylla spp. in South Sulawesi Waters}

\begin{abstract}
Morphological identification has limitations and can only be applied when entering the adolescent or adult phase, identification using DNA sequences is an alternative used in expressing taxonomy. The purpose of this study was to determine the DNA composition of the 18s rRNA ectoparasite Octolasmis cor gene and analyze phylogenetic and species identification. The results showed 18 rRNA molecular characteristics from O.cor parasite samples found in South Sulawesi region obtained DNA length $1500 \mathrm{bp}$ with base composition of Adenine 354 (23.6\%), Guanin $444(29.6 \%)$, Thymine $360(24 \%)$ and Citosin $342(15.1 \%)$. Based on the results of the phylogentic analysis, it shows a distance of 0.004 , which means it has a close relationship or possibility of the same species
\end{abstract}

Keyword : Analisis Filogenetik; Octolasmis cor; 18s rRNA 


\section{PENDAHULUAN}

Kepiting bakau (Scylla spp) merupakan komoditas perikanan yang hidup diperairan banyak digemari oleh konsumen domestik dan mancanegara. Sehingga kepiting bakau menjadi salah satu komoditas ekspor yang bernilai ekonomis (Domitilla et al. 2020). Namun benih kepiting bakau di Indonesia masih mengandalkan hasil tangkapan alam, terutama di Sulawesi Selatan. Kekurangan dari benih tangkapan alam sangat mungkin terinfestasi berbagai jenis parasit antara lain Octolasmis spp.

Octolasmis spp adalah jenis parasit dari kelas Maxillopoda yang sering dijumpai pada beberapa jenis crustacean seperti kepiting, lobster dan udang. Parasit ini terdiri dari peduncle dan capitulum yang di bungkus cangkang (Praptiasih, 2010) Parasit ini dapat berkembang pada lingkungan budidaya. karena siklus hidupnya tidak memerlukan inang perantara (Jeffries et al 1995).

Kondisi padat penebaran tinggi disertai dengan menurunnya kualitas air dapat meningkatkan infestasi. Hal ini di buktikan Irvansyah et al (2012) dengan melihat tingkat intesitas serangan parasit Octolasmis spp dari benih kepiting tangkapan alam mencapai $65,259 \%$ ketika dibesarkan dalam tambak. Infestasi Octolasmis spp yang berat diduga merupakan potensi ancaman terhadap perkembangan budidaya kepiting bakau, sehingga dapat memberikan dampak negatif terhadap pendapatan ekonomi masyarakat terutama petambak kepiting bakau.

Saat ini indentifikasi spesies octolasmis spp hanya dilihat jumlah capitular, scutum, tergum dan carina (Jeffries et al., 2005). Metode ini memiliki keterbatasan dan hanya bisa diaplikasikan pada saat parasit ini memasuki fase remaja atau dewasa, sedangkan pada fase larva atau cryprid teknik ini belum dapat diaplikasikan. Hal ini disebabkan pada fase cypird karakteristik morfologi belum terbentuk sehingga cukup sulit diidentifikasi. Alternative lain untuk metode Identifikasi adalah dengan menggunakan sekuens DNA, yaitu Salah satu penanda molekuler yang dipakai dalam mengungkapkan taksonomi suatu spesies dengan mengamati kode batang DNA atau DNA barcoding (Chippindale et al., 1999). Dari sekian banyak teknik penanda DNA, salah satunya adalah ribosomal RNA (rRNA). Menurut Baker et al., (2001) identifikasi spesies pada sub unit rRNA paling banyak digunakan sebagai molecular chronometer sebab dengan panjang 1600-2000 bp dapat memberikan informasi yang cukup tentang hubungan evolusi antar spesies.

Perkembangan teknik molekuler berdasarkan $18 \mathrm{~S}$ rRNA telah berkembang pada tahun 1996 dan sangat jarang digunakan 
sebagai alat indentifikasi organisme terutama di Indonesia,sehingga diharapkan dapat memberikan kontribusi besar bagi ilmu pengetahuan, selain itu juga untuk menambah informasi tentang karakter nukleotida 18s rRNA parasit Octolasmis spp serta mendesain pohon filogenetik molekulernya.

\section{METODE PENELITIAN}

\section{Waktu dan tempat Penelitian}

Penelitian ini dilaksanakan pada tahun lalu di laboratorium parasit dan penyakit ikan Universitas Hasanuddin Makassar. Sampel diawetkan semenjak tahun 2013 yang merupakan parasit yang mengifestasi kepiting bakau.

\section{Alat dan bahan.}

Adapun alat yang digunakan penelitian ini adalah botol eppendrof, Thermal Cycle (PCR), sumur gel eletroforesis, mikropipet, mesin $A B I$ 3130xl Genetic Analyzer dan UV transluminator. Sedangkan bahan yang digunakan adalah Parasit Octolasmis cor, etanol, DNA mini kit (Qiagen), primer, larutan TBE 0,5x, loading dye dan akuades

\section{Prosedur Penelitian}

DNA mini kit (Qiagen) digunakan untuk extraksi DNA dari Octolasmis cor dengan mengikuti prosedur. Amplifikasi DNA dengan menggunakan metode Reaksi Rantai Polimerase (PCR) sedangkan primer yang

http://ejurnal.ung.ac.id/index.php/jfpj/issue/archive digunakan dirancang dengan menggunakan software clustalW untuk daerah yang terkonservasi berdasarkan sekuen referensi GenBank di NCBI dan selanjutnya software pearlprimer digunakan dalam menentukan primer pada daerah yang terkonservasi tersebut dari region 18S. kondisi PCR $94^{\circ} \mathrm{C} 5$ menit (initial Denaturation), 30 siklus denaturasi dengan suhu $94^{\circ} \mathrm{C} 1$ menit, annealing suhu $45^{\circ} \mathrm{C} 1$ menit, dan ekstension disuhu $72^{\circ} \mathrm{C} 1,5$ menit dan final extension pada suhu $72^{\circ} \mathrm{C} 7$ menit

Produk PCR selanjutnya dielektroforesis dalam gel agarose 1\% dalam larutan TBE 0.5X. Sebanyak $10 \mu \mathrm{L}$ DNA hasil PCR dicampur dengan $2 \mu \mathrm{L}$ loading dye kemudian dimasukkan dalam sumur gel elektroforesis. Elekrtoforesis dijalankan pada tegangan 100 volt selama 30 menit. Selanjutnya gel hasil elektroforesis diletakkan diatas UV transluminator dan didokumentasikan menggunakan GelDoc (Sambrook et al. 1989).

DNA dipurifikasi dengan Qiagen PCR Purification Kit berdasarkan petunjuk kit. Kemudian hasil PCR yang sudah dipurifikasi disekuen dengan menggunakan sekuensing otomatis mesin ABI 3130xl Genetic Analyzer di Laboratorium 1st Base di Singapura. Selanjutnya dilakukan BLAST pada situs http://www.ncbi.nlm.nih.gov/BLAST. Hal ini bertujuan memastikan primer memotong tepat pada bagian dan untuk mengidentifikasi spesies 
Octolasmis spp. yang tersimpan dalam database NCBI untuk menentukan homolog (Sulistijowati dan Mile, 2016).

\section{HASIL DAN PEMBAHASAN}

Amplifikasi Octolasmis cor dari region $18 \mathrm{~S}$ rRNA telah berhasil diamplifikasi dengan panjang 1500 bp. Hal ini dapat dilihat pada Gambar 1.

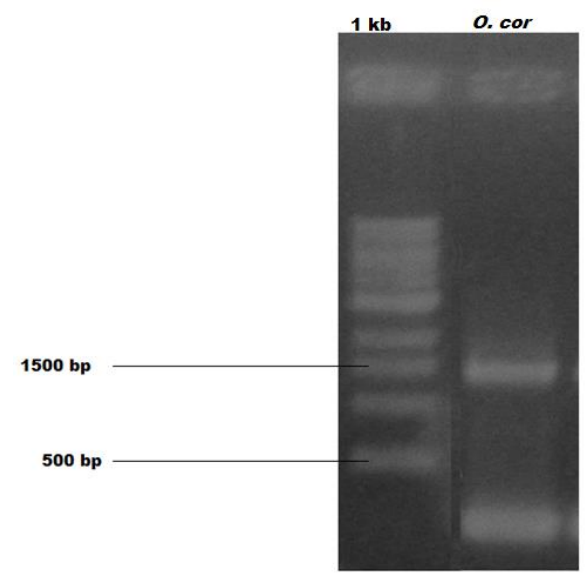

Gambar 1. Elektroforegram amplifikasi gen 18s rRNA specimen Octolasmis cor dalam $1 \%$ gel agarose (Keterangan: $1 \mathrm{~kb}=$ DNA Ladder, Octolasmis cor $=0$. cor $)$.

Hasil perhitungan (Gambar 2) jumlah basa nukleotida, diperoleh panjang DNA 1500bp dengan komposisi yaitu Adenin berjumlah 354 ( 23,6 \%), Guanin 444 (29,6\%), , Timin 360 (24 $\%$ ) dan Citosin 342 (15,1\%). Dari semua jumlah kandungan basa nukleotida terbanyak mencapai $29,9 \%$. Yaitu Guanin, akan tetapi jumlah tersebut tidak jauh berbeda dengan basa nukleotida yang lain.

Hasil blasting (Tabel 1) tingkatan kemiripan dimiliki oleh Octolasmis cor dengan max score 2760 dan totaly score 2670 , query cover 100\%, E-value 0.0 dan Ident 99,87 \%. Menurut Tindi (2017) bahwa nilai E-value sama dengan 0.0 menunjukkan pensejajaran sekuen yang signifikan artinya sekuen specimen yang dicari melalui situs NCBI pada penelitian ini berasal dari genus yang sama atau identik. Sehingga dapat dipastikan bahwa specimen O.cor adalah Octolasmis cor karena memiliki tingkat kemiripan atau per.indent 99,87 \%

Hasil analisis pohon filogenetik (Gambar 3) dengan menggunakan metode neighbor joining ditemukan jarak genetik sampel dengan Octolasmis cor menunjukan nilai 0,004 . Menurut Tallei et al. (2016), nilai jarak genetik yang semakin kecil antara dua organisme menunjukan kedekatan hubungan kekerabatan artinya semakin kecil jaraknya maka semakin dekat pula hubungan kekerabatan antara keduanya. Hasil di atas menandakan bahwa kemukinan besar bahwa spesies parasit yang ditemukan di wilayah Sulawesi Selatan adalah Octolasmis cor (Marcoz et al 2008) 
Tabel 1. Hasil BLASTING Specimen O.cor di Bank gen NCBI (3 teratas).

\begin{tabular}{lllllll}
\multicolumn{1}{c}{ Description } & Max & Total & Query & \multirow{2}{*}{ E value } & Per. Ident & \multirow{2}{*}{ Accession } \\
\hline Octolasmis cor 18S ribosomal RNA gene & 2760 & 2760 & $100 \%$ & 0,0 & $99,87 \%$ & EU082407.1 \\
Octolasmis sp. 18S ribosomal RNA gene & 2726 & 2726 & $100 \%$ & 0,0 & $99.47 \%$ & EU082408.1 \\
Iemnaspis amygdalum 18S ribosomal RNA & 2721 & 2721 & $100 \%$ & 0,0 & $99.40 \%$ & $\underline{\text { AB5551730.1 }}$ \\
\hline
\end{tabular}

Sumber: https://blast.ncbi.n/m.nih.gov/Blast.cgi

GATACATGGATAACTGTGGTAATTCTAGAGCTAATACATGCAACCGAGCCTCAGTCCAGCGCTTCGGTGTTGGCGGGGCG

CTTTTATTGGCTGAAAACCGATGGCTGCCCTCGTGGCGGTCGTTATTCGATGAATCACAATAACATTGTGTGGATCGCAC GGTCCTGTACCGGCGACGCGCCTTTCAAATATCTGCCTTATCAGCTCTCGACGGTTTGCTAGTGGCTGACCGTGGCTCTG ACGGGTAACGGGGAATATGGGTTCTATTCCGGAGAGGGAGCCTGAGAGATGGCTACCACATCTAAGGAAGGCAGCAGGCG CGTAACTTACCCACTCTCAGTTCGAGGAGGTAGTGACAATAAATACCTTACAGAGGTCTCGTTAACCGAGATCTCTCAAA CGGAATGAGTACAACGTGAATCCTTTAACGAGGATCGACTGGAGGGCAAGCCTGGTGCCAGCAGCCGCGGTAATTCCAGC TCCAGTAGCGTATATTAAAGCTGTTGCGGTTAAAAAGCTCGTAGTTGGATATCAGTGCGTGTCCGGTCCGGCATGCCCGG TGCGTTATGGCGGCAACGCGATGACGCCCGGGCTCCCAAATGTCGGCTGGCCGCATTCAATCGTGTCGGATCCGTCGACG GGCCGTTCTTCGGAGGGGCCTGTTGGCGACCGGCGGCGTTACCTTGAACAAATTAGAGTGCTCAAAGCAGGCTCTTAATG СCTGTATACATATTCATGGAATTGGAGAATACGTCCCTGGCTCGATTTGGTTGGTTTTGAGAGTCGAAGGGAAATGATTA ATAGGGACTGACGGAGGCATTCGTATTGCGACGCGAGGGGTGAAATCCTGTGACCGTCGCACGACGAACTACTGCGAAAG CATTTGCCGAGAATGTTTTCATTAGTCAAGAACGAAAGTTAGAGGTTCGAAGGCGATCAGATACCGCCCTAGTTCTAACC GTAAACGATGTCGACCAGCAATCCGCAACGGTCACTTAAAGGACTGTGCGGGCAGCTTTCCCGGAGAAATCAGAGTGTTT GGACTCCGGGGGAATTATGGTTGCAAAGCTGAAACTTAAAGGAATTGACGGAAGGGCACCACCAGGAGTGGAGCTTGCGG CTTAATTTGACTCAACACGGGACAACTCACCAGGCCCGGACACCGTAAGGATTGACAGACTGATAGCTCTCTCTTGATTC AGTGGGTGGTGGTGCATGGCCGTTCTTAGTTGGTGGAGTGATTTGTCTGGTTTATTCCGATAACGAACGAGACTCTGGCC TATTAAACTTGACGCCGCCAGTCCTTATGTGACTGGGGTGTGCTTCTTAGAGGGATCATCGGCGTCCCAGCCGAAGGAAA GGGAGCAATAACAGGTCTGTGATGCCCTTAGATGTTCTGGGCTGCACGCGTGTTACACTGAAGTGGTCAGCGCGCCGTTC AACGTCCTTCTCCGAGAGGAGCGGGCAAACGTTTGAACCCTTTTCGTGATGGGAATGGGG

Gambar 2. Consensus DNA parasit Octolasmis cor asal perairan Sulawesi Selatan Specimen O.cor.

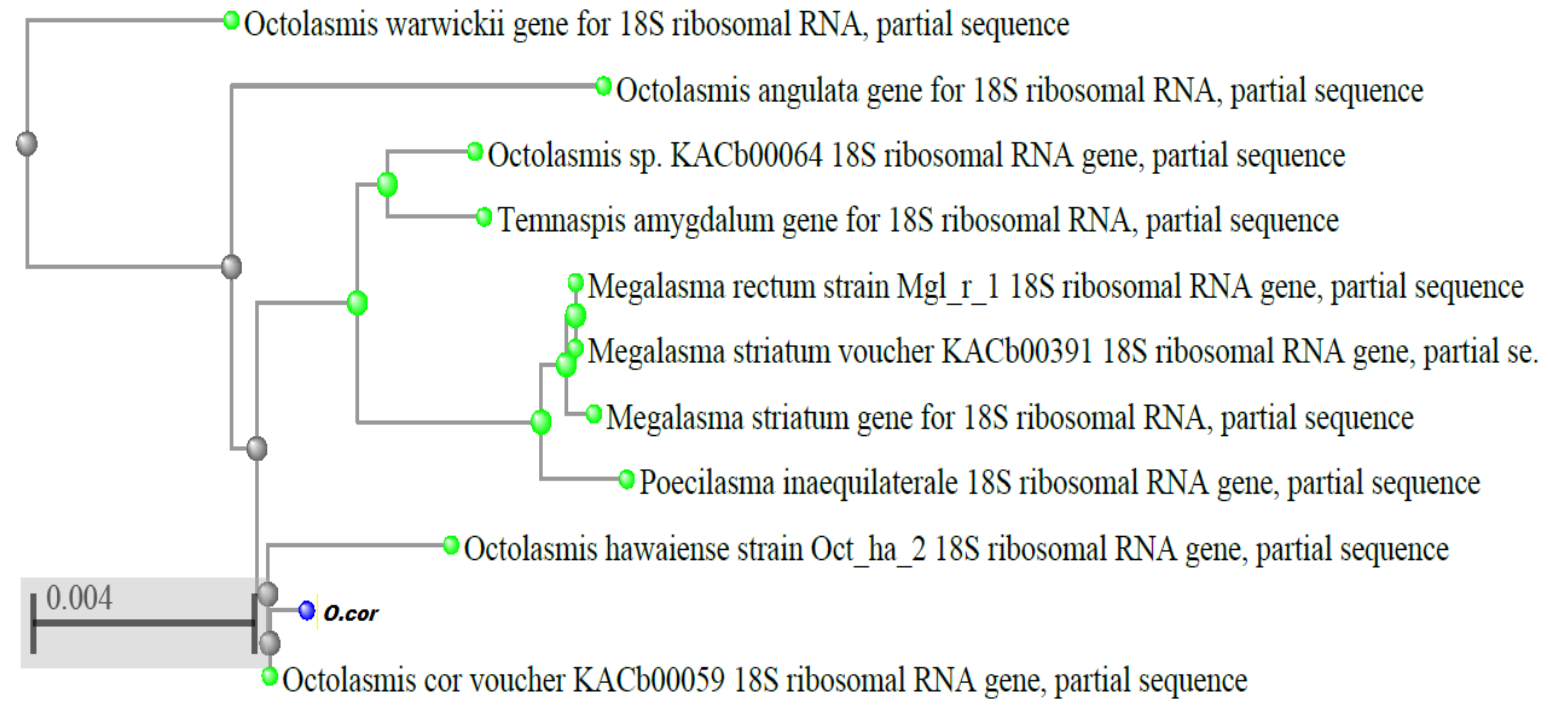

Gambar 3. Rekonstruksi pohon filogenetik beberapa jenis kerabat Octolasmis spp. berdasarkan $18 \mathrm{~S}$ rRNA gen dengan metode neighbor joining

http://ejurnal.ung.ac.id/index.php/jpj/issue/archive 
Hasil pengamatan morfologi dari sampel parasit yang ditemukan memiliki kesamaan dengan Octolasmis cor (Chan et al .2012). Hal ini bisa dilihat dari jumlah cabang scutum, tergum dan carina pada kedua gambar parasit itu. Octolasmis cor memiliki jumlah cabang scutum terdiri dari 2 cabang dan 1 carina (Gambar 4a), salah satu ciri khas dari bentuk cabang scutum daro Octolasmis cor agak melebar.

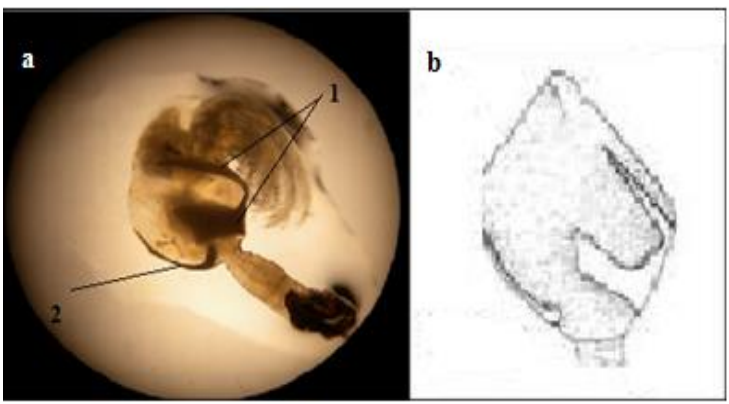

Gambar 4. a) Morfologi Octolasmis cor pada kepiting bakau yang tertangkap di Sulawesi selatan; b) Gambar O.cor (Chan et al .2012)

\section{SIMPULAN}

Karakteristik molekuler 18 rRNA dari sampel parasit O.cor yang ditemukan di wilayah Sulawesi Selatan diperoleh panjang DNA 1500 bp dengan komposisi basa Adenin 354 (23,6\%), Guanin 444 (29,6 \%), , Timin 360 (24\%) dan Citosin $342(15,1 \%)$. Berdasarkan hasil analisis filogentik menunjukan jarak 0,004 yang artinya memiliki kedekatan hubungan atau kemungkinan dari spesies yang sama. Saran untuk penelitian ini diharapkan untuk dapat mengidentifikasi karakteristik DNA parasit pada gen $28 \mathrm{~S}$ atau COI.

\section{DAFTAR PUSTAKA}

Baker, G.C., Shabarni-Gaffar, Cowon, D.C., Suharto, A.R. 2001. Microbial community analysis of Indonesian hot-springs. FEMS Microbial Lett. 103-9.

Chan, K.K., Prabowo, Romanus, Lee, KwenShen. 2012. Octolasmis cor (Aurivillius, 1892).

http://barnacle.biota.biodiv.tw/pages/1059 [diakses tanggal 14 agustus 2013].

Chippindale, P.T., Dave, V.K, Whitmore, D.H., Robinson, J.V. 1999. Phylogenetic relationships of North American Damselflies of the Genus/schnura (Odonata: Zygoptera: Coenagrionidae) based on sequences of three mitochondrial genes. Molecular Phylogenetics and Evolution. 11(1): 110121.

Domitila, Ohoiulun., Marthinus, I. H. H. 2020. Analisis Morfometrik Kepiting Bakau (Scylla Serrata) Hasiltangkapan Dari Perairan Desa Warwut Kabupaten Maluku Tenggara. Jambura Fish Processing Journal. 2(1): 28-35.

Irvansyah, M., Yusuf, Nurlita A., Gunanti M. 2012. Identifikasi dan intensitas ektoparasit pada kepiting bakau (Scylla serrata) stadia kepiting muda di pertambakan kepiting, kecamatan Sedati, Kabupaten Sidoarjo. Jurnal Sains Dan Seni ITS 1(1).

Jeffries, William, B., Harold, K., Voris, P.N., Somsak, P. 2005. Pedunculate Barnacles of the symbiotic genus Octolasmis (Cirripedia: Thoracica: Poecilasmatidae) 
from the Northern Gulf of Thailand The Natural History. Journal of Chulalongkorn University 5(1): 9-13.

Jeffries, William, B., Harold, K., Voris, Sombat, P., Heil, L.C. 1995. The live cycle Lepadhormorph barnacle, Octolasmis cor and methods for their laboratory culture. Phuket Marine Biol. Cent. Bull. 29-35.

Marcos P'erez-Losada, Jens, T., Hoeg, Keith, A., Crandall. 2004. Unraveling the evolutionary radiation of the Thoracican barnacles using molecular and morphological evidence: A comparison of several divergence time estimation approaches. Society of Systematic Biologists. 53(2):244-264.

Praptiasih, Indah. 2010. Mengenal Octolasmis, parasit leher angsa pada Crustacea. Info Karikan, edisi ketujuh. Pusat Karantian Ikan.

Sambrook, J., Fritsch, E.F., Maniatis, T. 1989. Molecular Cloning: A Laboratory Manual. New York:Cold Spring Harbor Laboratory Press. 113-127 p.

Sulistijowati, R., Mile, L.. 2016. Identification of Lactic Acid Bacteria Isolates from Intestine of Milkfish (Chanos-Chanos) Potential Activity against Pathogen Bacteria Used PCR 18s Rrna Methode. International Journal of BioScience and Bio-Technology. 8(3).

Tallei, T.E., Rembet, R.E., Pelealu, J.J., Kolondam, B.J. 2016. Sequence variation and phylogenetic analysis of Sansevieria trifasciata (Asparagaceae). Bioscience Research. 13(1): 01-07.

Tindi, Monalisa, N., Gustaf, F., Mamangkey, Stenly, W. 2017. DNA barcode dan analisis filogenetik molekuler beberapa jenis bivalvia asal perairan Sulawesi Utara berdasarkan gen Coi. Jurnal Pesisir dan Laut Tropis. 1: 2. 